\title{
TUMBUHAN BAWAH PADA PERKEBUNAN KELAPA SAWIT TUA (TM) DAN SAWIT MUDA (TI) DENGAN PEREMAJAAN TEKNIK UNDERPLANTING DI PT. BIO NUSANTARA TEKNOLOGI
}

\author{
Trisna $^{1)}$, Wiryono $^{2)}$, Enggar Apriyanto ${ }^{2)}$ \\ ${ }^{1)}$ Mahasiswa Program Pascasarjana Pengelolaan Sumberdaya Alam UNIB \\ 2) Jurusan Kehutanan Fakultas Pertanian UNIB
}

\begin{abstract}
ABSTRAK
Komoditas kelapa sawit secara nasional dari segi luas dan produksinya semakin meningkat setiap tahunnya selama kurun waktu tiga tahun terakhir yaitu pada tahun 2015-2017. Tahun 2015 luas area perkebunan, tahun 2015 mencapai 11.260.277 ha/th dan pada tahun 2017 sebesar 12.307.677 ha/th. Faktor yang lain yaitu produksi kelapa sawit sebesar 31.070.015 ton/th dan pada tahun 2017 sebesar 35.359.384 ton/th (Dirjen Perkebunan, 2017). Akhir-akhir ini, perusahaan perkebunan baik milik negara maupun rakyat mulai melakukan pembaharuan dalam proses peremajaan. Permasalahan yang timbul pada saat peremajaan adalah tumbuhan bawah yang tumbuh dengan sangat cepat dan sulit untuk dikendalikan yang mengganggu tanaman akibat dari peremajaan secara konvensional sehingga dikembangkan teknik baru yaitu underplanting. Peremajaan dengan teknik konvensional ini sering ditemui permasalahan seperti biaya yang tinggi, terbukanya lahan secara besar-besaran dan timbulnya erosi. Penelitian ini bertujuan untuk menganalisis komposisi jenis tumbuhan bawah serta jenis asing dan jenis asli yang tumbuh pada tiga kondisi kebun kelapa sawit di PT. Bio Nusantara Teknologi (sawit yang tua (TM dan sawit muda (TI)) dan menghitung indeks keragaman jenis tumbuhan bawah pada ketiga kondisi kebun kelapa sawit. Metode penelitian yang digunakan adalah metode kuadrat. Ukuran kuadrat yang digunakan adalah 1x1 m. Banyaknya jumlah kuadrat mengacu pada metoda kurva spesies area dengan luas minimum $40 \mathrm{~m}^{2}$. Hasil penelitian menunjukkan bahwa komposisi tumbuhan bawah pada TM ditemukan 20 jenis yang terdiri dari 5 jenis asli dan 15 jenis asing dan pada kebun TI ditemukan 20 jenis yang terdiri dari 8 jenis asli dan 12 jenis asing. Tingkat keragaman jenis tumbuhan bawah (H') tergolong rendah dengan besaran masing-masing pada TM sebesar 0,637 dan TI dengan nilai 1,94. Jenis yang mendominasi pada kedua kondisi kebun kelapa sawit adalah Axonopus compressus dengan INP 130,238\% (TM) dan 42,237\% (TI).
\end{abstract}

Kata Kunci: Kelapa Sawit, Underplanting, Komposisi Tumbuhan Bawah, Keragaman Jenis, Metode Kuadrat, Kurva Species Area

\section{PENDAHULUAN}

Perkembangan luas dan produksi kelapa sawit yang semakin tinggi mengakibatkan peningkatan peruntukan lahan menjadi kebun kelapa sawit sehingga perlu pengelolaan yang intensif. Hal ini akan berpengaruh terhadap keragaman tumbuhan bawah karena pembukaan hutan akan mengubah iklim mikro. Hutan yang relatif tertutup oleh tanaman pohon maka akan berubah menjadi lebih terbuka. 
Kebun kelapa sawit memiliki kecenderungan penutupannya lebih terbuka karena jaraknya tajuknya lebar sehingga tumbuhan bawah akan cepat memenuhi ruang yang terbuka. Tumbuhan bawah ini disebut juga tumbuhan pioner yang tumbuh pada lahan yang baru dibuka. Tumbuhan bawah akan berpengaruh pada pertumbuhan tanaman kelapa sawit baik berdampak positif maupun negatif. Dampak positif tumbuhan bawah yaitu land cover (tanaman penutup tanah). Tanaman penutup tanah dapat dikelola untuk menutupi permukaan tanah untuk menghindari erosi karena jatuhnya air hujan tidak langsung mencapai tanah melainkan jatuh ke daundaun tumbuhan. Manfaat lain tumbuhan bawah yaitu sebagai tanaman obat, tanaman hias dan pakan ternak.

Nursyiwan (2014) menyatakan bahwa Mucuna bracteata dengan nama lokal koro rawe merupakan tumbuhan bawah yang berfungsi sebagai penutup tanah. Tumbuhan ini hidup secara menjalar dan dapat hidup pada kondisi ternaungi maupun tanpa naungan. Jenis ini berperan dalam memperbaiki kesuburan fisik dan kimia tanah serta dapat menekan pertumbuhan gulma. Tumbuhan ini dapat mempercepat matang sadap dan memperbaiki produksi lateks di areal kebun karet.

Permasalahan yang timbul pada saat peremajaan adalah tumbuhan bawah yang tumbuh dengan sangat cepat dan sulit untuk dikendalikan yang mengganggu tanaman akibat dari peremajaan secara konvensional. Peremajaan dengan teknik konvensional ini sering ditemui permasalahan seperti biaya yang tinggi, terbukanya lahan secara besar-besaran dan timbulnya erosi. Ditemukan alternatif teknik peremajaan yaitu teknik underplanting menggunakan infus herbisida, keuntungannya yaitu perubahan ekosistem tidak drastis, biaya lebih murah, mengurangi resiko erosi pada lahan terbuka dan perubahan tumbuhan bawah diduga lebih tetap. Pembukaan lahan dengan perlahan ini akan berpengaruh terhadap perubahan tumbuhan bawah di ke- bun kelapa sawit baik jenis, kerapatan dan penutupan.

Tujuan penelitian ini adalah untuk menganalisis komposisi jenis tumbuhan bawah serta jenis asing dan jenis asli yang tumbuh pada dua kondisi kebun kelapa sawit di PT. Bio Nusantara Teknologi (sawit tua (TM) dan sawit muda (TI)) serta menghitung indeks keragaman dan dominansi jenis tumbuhan bawah pada kedua kondisi kebun kelapa sawit di PT. Bio Nusantara Teknologi. Informasi keragaman dan kerapatan jenis tumbuhan bawah dengan mematikan kelapa sawit yang sudah tua dengan teknik underplanting belum banyak diteliti, khususnya di PT Bio Nusantara Teknologi, Kabupaten Bengkulu Tengah, Provinsi Bengkulu, maka peneliti tertarik untuk melakukan penelitian ini.

\section{METODE PENELITIAN}

\section{Tempat dan Waktu Penelitian}

Penelitian ini dilaksanakan pada kebun kelapa sawit yang terletak di kawasan PT. Bio Nusantara Teknologi, Desa Pondok Kelapa, Kecamatan Pondok Kelapa, kabupaten Bengkulu Tengah, Provinsi Bengkulu. Waktu pelaksanaan penelitian selama 2 bulan yaitu pada bulan Februari - Maret 2018.

\section{Kondisi Umum Lokasi Penelitian}

Lokasi penelitian memiliki topografi areal $80 \%$ berbukit ( lahan kelas IV ), secara umum jenis tanah podzolik merah kuning dan kesesuaian curah hujan cukup ideal untuk pertumbuhan kelapa sawit. Secara Geografis, terletak antara $3^{0} 33^{\prime}-$ $3^{0} 42^{\prime}$ LS, dan $102^{0} 16^{\prime}-102^{0} 27^{\prime}$ BT, dengan jarak $\pm 24 \mathrm{KM}$ sebelah utara Kota Bengkulu dengan kondisi lokasinya berbatasan langsung dengan 4 Kecamatan di Kabupaten Bengkulu Tengah, yaitu :

Menurut Nurhasanah (2014) Sebelah Utara: Desa Tiambang, Kec. Pematang 
Tiga, Sebelah Selatan : Desa Sunda Kelapa, Kec. Pondok Kelapa, Sebelah Barat: Desa Talang Jambu, Kec. Kerkap, Sebelah Timur : Desa Kertapati, Kec.Taba Penanjung.

Titik penelitian berada di dua kondisi kebun kelapa sawit yaitu pada sawit tua (TM) dan sawit muda (TI). Jarak tanam seragam yaitu $8 \times 8 \mathrm{~m}$. Dua kebun kelapa sawit yang diamati tumbuhan bawahnya dapat dilihat pada Gambar 1.

\section{Alat dan Bahan}

Alat dan bahan yang digunakan dalam penelitian meliputi Alat tulis, Tali raffia, Meteran gulung, Kantong plastik, Lux meter, Thermometer, Tally sheet, Kamera, Hygrometer, Bingkai kayu ukuran 1x1m, $25 \times 25 \mathrm{~cm}$, Buku identifikasi tumbuhan bawah

\section{Jenis Data}

Jenis data diambil dalam penelitian ini terdiri dari : 1). Data primer, Data primer berupa nama jenis, jumlah jenis, persen penutupan dan foto tumbuhan serta kondisi

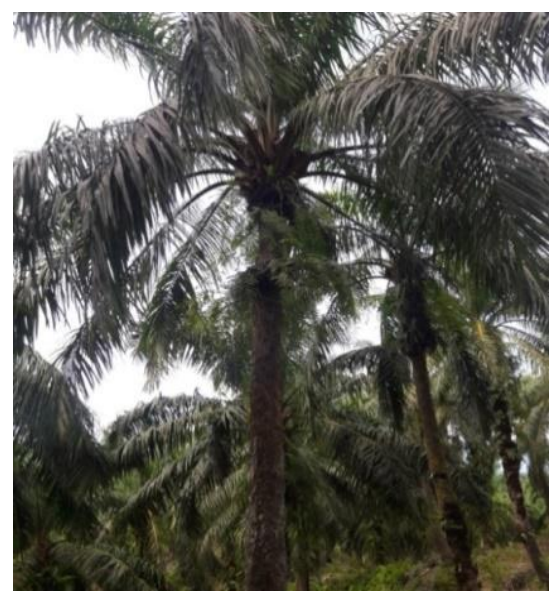

(a) kebun kelapa sawit. Data lain yang diamati adalah data faktor lingkungan di kebun kelapa sawit yang diamati yaitu suhu, kelembaban, curah hujan dan intensitas cahaya. Selain itu, ada pula sampel tanah yang diambil disetiap kondisi kebun kelapa sawit untuk dianalisis di laboratorium Ilmu Tanah Universitas Bengkulu yaitu kandungan $\mathrm{N}, \mathrm{P}, \mathrm{K}, \mathrm{pH}$, bahan organik, struktur tekstur dan bobot volume (BV), 2). Data sekunder, Data ini berupa data identifikasi jenis tumbuhan bawah berupa nama ilmiah dan habitus spesies serta data kondisi lokasi penelitian secara umum meliputi letak, luas, kondisi fisik yang diperoleh dari perusahaan PT. Bio Nusantara Teknologi dan literatur yang bersumber dari buku, jurnal dan internet.

\section{Metode Pengumpulan Data}

Pengumpulan data jenis tumbuhan bawah menggunakan metode kuadrat. Ukuran kuadrat yang digunakan berdasarkan metode ini adalah $1 \times 1 \mathrm{~m}$.

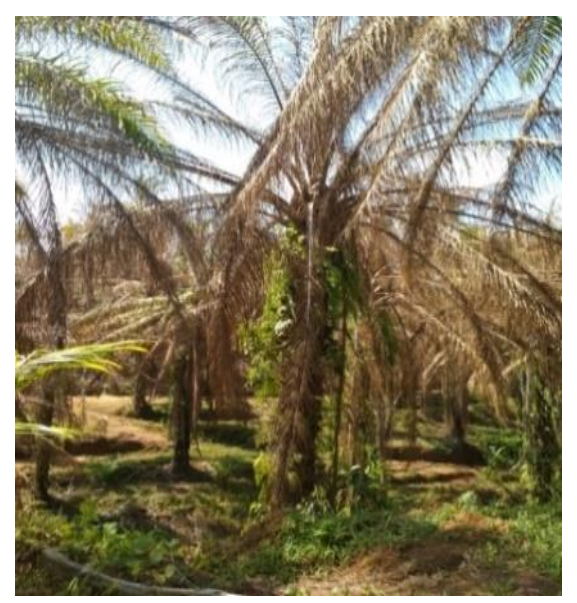

(b)

\section{Gambar 1. Kebun kelapa sawit yang diamati tumbuhan bawahnya : (a) TM (b) TI}

Penempatan kuadrat dilakukan secara sistematis dengan jarak disesuaikan dengan luas lokasi dengan awal acak dan mewakili kondisi lapangan (zona), kerapatan dan jenis yang tampak. Setelah kuadrat ditentukan, dilakukan pengukuran 
persen penutupan dan penentuan jenis. Banyaknya jumlah kuadrat mengacu pada metoda kurva spesies area. Jumlah dianggap cukup apabila jumlah jenis yang didapatkan tidak bertambah dengan bertambahnya jumlah kuadrat (Wiryono, 2009).

Sampel yang merambat tetap dihitung meskipun batang pokoknya tidak berada di dalam plot, sedangkan batang yang tegak hanya dihitung apabila batang pokok berada di dalam plot. Semua jenis herba termasuk rumput tidak dibatasi tingginya, sedangkan untuk perdu hanya yang

\section{HASIL DAN PEMBAHASAN}

\section{Komposisi Jenis Tumbuhan Bawah}

Penelitian ini dilakukan di dua kondisi kebun kelapa sawit yang berbeda yaitu sawit tua (TM) dan sawit muda (TI). Kebun sawit tua (TM) ditemukan tumbuhan bawah sebanyak 20 jenis dan 12 famili. Kebun kelapa sawit yang muda (TI), tumbuhan bawah yang ditemukan yaitu 20 jenis dan 14 famili. Perbandingan Komposisi jenis tumbuhan bawah yang berada di kebun kelapa sawit tua (TM) dan kebun kelapa sawit muda (TI) yang memiliki jenis yang sama sebanyak 7 jenis dengan penutupan jenis tertinggi ditunjukkan oleh Axonopus compressus.

Jumlah jenis dan jumlah famili tumbuhan bawah disajikan dalam Gambar 2 . Hal ini dapat terjadi karena jenis yang tumbuh di dua kondisi kebun kelapa sawit ini diduga memiliki sifat yang mudah tumbuh di berbagai keadaan lingkungan dan jenis tanah. Jenis tumbuhan bawah yang hanya terdapat pada TM sebanyak 7 jenis dan pada TI sebanyak 11 jenis. Jenisjenis tersebut ditunjukkan pada Tabel 2 . berukuran kurang dari atau sama dengan 1,5 m saja.

Sketsa plot tumbuhan bawah ditentukan dengan pertimbangan bahwa kebun kelapa sawit seragam dengan jarak tanam $8 \mathrm{~m} \times 8 \mathrm{~m}$, lokasi relatif datar dan waktu pengambilan data sama.

\section{Analisis Data}

Analisis data untuk mengetahui gambaran tentang komposisi jenis dan data ekologi tumbuhan bawah, dilakukan perhitungan terhadap parameter yang meliputi indeks nilai penting (INP), indeks keragaman jenis $\left(H^{\prime}\right)$, indeks kemerataan jenis (E) dan indeks kesamaan komunitas (IS $\left.\mathrm{S}_{\mathrm{E}}\right)$.

Kurva species area menggambarkan komposisi jenis dan penutupan tumbuhan bawah di sawit tua (TM) dan sawit muda (TI) dapat diihat pada Gambar 3. Jumlah plot adalah 40 dengan luas plot sebesar 40 $\mathrm{m}^{2}$, dengan luas minimum $31 \mathrm{~m}^{2}$ tidak mengalami penambahan jenis lagi dianggap sudah mewakili kondisi jenis di lapangan

Intensitas cahaya yang diperoleh pada kebun sawit tua (TM) paling rendah dibandingkan sawit muda (TI). Berturutturut pada TM dan TI sebesar 5166 dan 7266 1x. Hal ini akan mempengaruhi jenis tumbuhan bawah yang tumbuh. Jenis yang dominan adalah rumput yang berdaun sempit seperti $A$. compresus yang tumbuh paling banyak daripada jenis lain. Instensitas cahaya yang rendah akan mengurangi keragaman jenis di TM sehingga A. compresus yang bersifat sangat adaptif terhadap semua kondisi lingkungan akan mendominasi di lahan tersebut. 


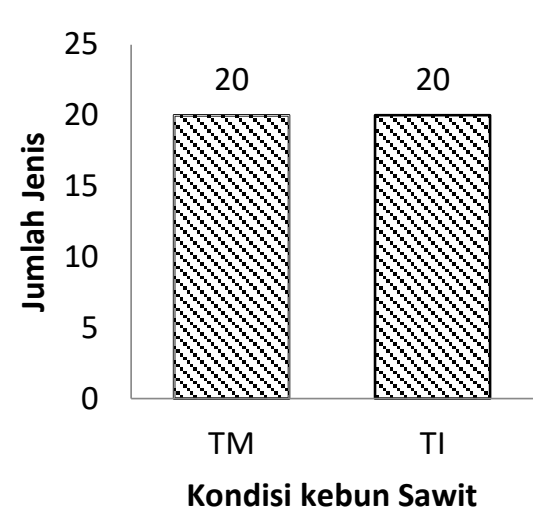

(a)

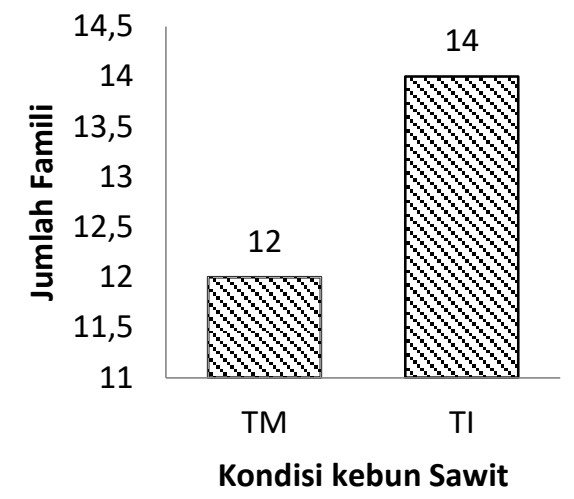

(b)

Gambar 2. Komposisi tumbuhan bawah di TM dan TI berdasarkan (a) Jenis tumbuhan bawah, (b) Famili tumbuhan bawah

Tabel 1. Komposisi jenis tumbuhan bawah pada kebun kelapa sawit tua (TM) dan kebun kelapa sawit muda (TI)

\begin{tabular}{|c|c|c|}
\hline \multirow{2}{*}{ NAMA JENIS } & \multicolumn{2}{|c|}{ PENUTUPAN (\%) } \\
\hline & $\mathrm{TM}$ & $\mathrm{TI}$ \\
\hline Axonopus compressus & 3283 & 1567 \\
\hline Cyperus kyllingia & 43 & 1430 \\
\hline Nephrolepis biserata & 83 & 6 \\
\hline Asystasia indica & 14 & 36 \\
\hline Stachytarpheta indica & 67 & 53 \\
\hline Colocasia esculenta & 36 & 36 \\
\hline Elaeis guineensis & 7 & 20 \\
\hline Imperata cylindrica & - & 414 \\
\hline Spermacoce latifolia & - & 13 \\
\hline Synedrella nudiflora & 1 & - \\
\hline Desmodium canadense & 4 & - \\
\hline Ageratum conyzoides & 3 & - \\
\hline Pylanthus urinaria & 9 & - \\
\hline Cyperus rotundus & 1 & - \\
\hline Eragrostis tenella & 50 & - \\
\hline Eleusine indica & - & - \\
\hline Mimosa pudica & - & - \\
\hline Hyptis rhomboidea & - & - \\
\hline Ludwigia hyssopifolia & - & - \\
\hline Hyptis suaveolens & - & - \\
\hline Peperomia pellucida & - & - \\
\hline Fimbristylis miliacea & - & - \\
\hline Tetracera scardens & - & - \\
\hline Croton hirtus & - & - \\
\hline
\end{tabular}


Sida rhombifolia

Mikania micrantha

Sida acuta

Thirumfetta rhomboidea

Elepanthopus scaber

Vernonia cinerea

Mucuna cochinchinensis

Scleria bancana

Dicranopteris linearis

Mucuna pruriens

Clidemia hirta

Chromolaena odorata

Melastoma malabathricum

Setaria barbata

Leptochloa chinensis

Tetracera indica

Centella asiatica

Hyptis capitata

Acroceras macrum

Oxalis barrelieri

Desmodium triflorum

Mimosa pigra

Galinsoga parviflora

Eclipta prostrate

Jumlah

\section{Dominansi Jenis Tumbuhan Bawah}

Jenis-jenis tumbuhan bawah yang ada di tiga kebun kelapa sawit yaitu jenis $A$. compressus, C. kyllingia, A. indica, $E$. guineensis, $N$. biserata, $S$. indica dan $C$. esculenta. Jenis yang paling dominan adalah A. compressus dengan INP $130,238 \%$ di bawah tanaman menghasilkan (TM). Jenis dominan pada suatu komunitas adalah jenis yang dapat beradaptasi dan memanfaatkan lingkungan yang ditempatinya secara efisien daripada jenis-jenis lainnya

Jenis-jenis dominan digunakan parameter Indeks Nilai Penting (INP) menunjukkan INP paling tinggi merupakan jenis yang paling dominan dalam suatu komunitas (Pananjung, 2013).

Tumbuhan bawah yang dominan pada kebun kelapa sawit yang tua (TM). Jenis yang paling dominan yaitu jenis rumput gajah mini (Axonopus compressus) dengan INP sebesar 130,238\%. Kebun kelapa sawit yang sudah diinfus (TI) menunjukkan jenis rumput gajah mini (Axonopus compressus) sebagai spesies tumbuhan bawah paling dominan dengan nilai INP sebesar $42,237 \%$. 


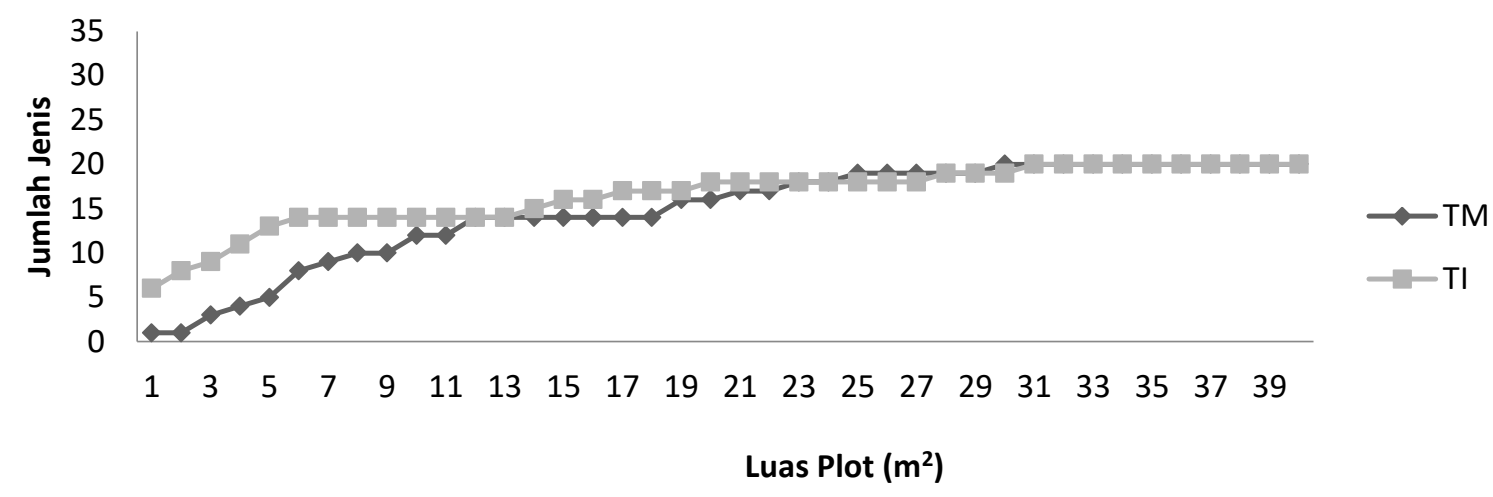

\section{Gambar 3. Kurva species area pada kebun kelapa sawit tua (TM) dan kebun kelapa sawit muda (TI)}

Jenis-jenis dominan digunakan parameter Indeks Nilai Penting (INP) menunjukkan INP paling tinggi merupakan jenis yang paling dominan dalam suatu komunitas (Pananjung, 2013). Tumbuhan bawah yang dominan pada kebun kelapa sawit yang tua (TM). Jenis yang paling dominan yaitu jenis rumput gajah mini (Axonopus compressus) dengan INP sebesar 130,238\%. Kebun kelapa sawit yang sudah diinfus (TI) menunjukkan jenis rumput gajah mini (Axonopus compressus) sebagai spesies tumbuhan bawah paling dominan dengan nilai INP sebesar 42,237\%.

Axonopus compresus adalah salah satu jenis rumput dengan famili Poaceae dan berasal dari Amerika Selatan. Tumbuhan bawah ini tumbuh menyebar di seluruh Indonesia. Habitat jenis ini yaitu di lahan yang kering, pada dataran rendah sampai dataran tinggi lebih kurang 1400 mdpl serta tumbuh baik di tempat terbuka atau terlindung. Persyaratan tumbuh jenis ini, dapat tumbuh baik pada tanah yang berpasir atau berpasir lempung tanah, tetapi juga untuk tanah liat dan gambut, berkembang di tanah yang terlalu subur. Terbaik di tanah asam dengan $\mathrm{pH}$ (5-7), klorosis besi di atas $\mathrm{pH} 7$. Toleransi rendah salinitas $(<4 \mathrm{dS} / \mathrm{m})$. Umumnya ditemukan di daerah dengan curah hujan tahunan dari 800-5000 mm. Jenis ini biasanya ditemukan di daerah subtropis dan tropis dataran tinggi, tampaknya menjadi yang terbaik disesuaikan dengan daerah tropis dataran rendah. Tumbuh baik di tempat teduh, sering membentuk tikar tebal di bawah padat pohon kanopi. Tumbuhan ini dianggap sebagai penutup tanah yang baik di bawah perkebunan kelapa sawit dan karet (Novitria, 2014).

Jenis Cyperus kyllingia merupakan herba menahun yang memiliki akar rimpang pendek, merayap. Batang bersegi tiga tajam. Daun bentuk garis, sempit berlunas, dan lebarnya 2-4 mm. Bunga berupa bongkol semu berbentuk bola telur atau bulat memanjang, berwarna putih dengan anak bulir yang tersusun spiral. Buah bulat memanjang, sedikit gepeng, coklat muda, dan berjerawat halus (Kasmo, 1986). Tumbuhan ini umumnya dijumpai pada daerah terbuka seperti tempat pembuangan, tepi jalan, yang merupakan tumbuhan bawah pertanian yang potensial. Kondisi terbaik untuk pertumbuhan $C$. kyllingia dengan suhu rata-rata $25^{\circ} \mathrm{C}$. Umbi teki mampu berkecambah pada suhu $10^{\circ}$ - $40^{\circ} \mathrm{C}$. $\mathrm{pH}$ tanah untuk menumbuhkan rumput teki berkisar antara 4-7,5 (Moenandir, 1993). Perkembangbiakan $C$. kyllingia dengan biji dan rimpang (Kasmo, 1986).

\section{Jenis asing dan jenis asli}

Kebun kelapa sawit yang tua (TM) menunjukkan 15 jenis tumbuhan asing dan 5 jenis asli. Jenis asing memiliki jenis A.compressus yang berasal dari Amerika Selatan dengan INP sebesar 130,238\%. Sebagai spesies dominan dengan INP sebesar 9,574\% Spesies Cyperus kyllingia 
merupakan spesies asli yang dominan yang berasal dari Asia.

Kebun kelapa sawit yang muda (TI) terdiri dari jenis asing dan asli. Jenis asing yang dominan dengan sebanyak 12 buah dengan jenis yang dominan yaitu Axonopus compressus yang berasal dari Amerika selatan dengan INP sebesar $42,237 \%$. Jenis asli terdiri dari 8 jenis dengan jenis yang dominan adalah Cyperus kyllingia dari Asia dengan INP sebesar 40,192\%.

\section{Analisis Keragaman Tumbuhan Bawah}

Suatu komunitas dikatakan memiliki keragaman jenis yang tinggi jika komunitas itu disusun oleh banyak jenis. Keragaman jenis tumbuhan ditunjukkan dengan indeks keragaman jenis (H'). Nilai keragaman jenis pada kebun kelapa sawit yang sudah diinfus (TI) lebih tinggi dibandingkan kebun kelapa sawit yang lain dapat dilihat pada Tabel 2. Kemerataan jenis dianggap maksimum jika semua jenis memiliki jumlah individu yang sama. Kemerataan jenis terjadi jika terdapat beberapa jenis hidup bersama dalam satu habitat (Pananjung, 2013).

\section{Kesamaan komunitas $\left(\mathrm{IS}_{\mathrm{E}}\right)$ tumbuhan bawah}

Tabel 2. Indeks Keragaman Jenis (H'), Indeks Kemerataan Jenis (E) Tumbuhan Bawah di Bawah Kebun Kelapa Sawit Belum Menghasilkan (TBM), Sawit Yang Sudah Diinfus (TI) dan Sawit Menghasilkan (TM)

\begin{tabular}{clcc}
\hline No & \multicolumn{1}{c}{ Kondisi Sawit } & H' & E \\
\hline 1 & Sawit menghasilkan (TM) & 0,637 & 0,212 \\
2 & Sawit sudah diinfus (TI) & 1,94 & 0,648 \\
\hline
\end{tabular}

\section{KESIMPULAN}

Kesimpulan dalam penelitian ini adalah

1. Komposisi tumbuhan bawah yang tumbuh pada tiga kondisi kebun kelapa sawit di PT Bio Nusantara Teknologi yaitu pada kebun kelapa tua (TM) ditemukan 20 jenis yang terdiri dari 5 jenis asli dan 15 jenis asing dan pada
Indeks kesamaan komunitas (IS $\left.\mathrm{S}_{\mathrm{E}}\right)$ artinya membandingkan komposisi jenis tumbuhan yang berada di dua komunitas. Menurut Istomo dan Kusmana (1997), jika nilai $\mathrm{IS}_{\mathrm{E}}<75 \%$ maka dua komunitas yang dibandingkan dianggap berbeda, dan jika nilai $\mathrm{IS}_{\mathrm{E}} \geq 75 \%$ maka kedua komunitas yang dibandingkan dianggap sama. Jenisjenis yang ditemukan pada kedua tanaman tersebut dapat membantu perbaikan stuktur tanah sehingga dapat membantu regenerasi pertumbuhan berikutnya. Indeks kesamaan komunitas ditunjukkan pada Tabel 3.

Indeks kesamaan antara kebun sawit tua (TM) dan kebun sawit yang muda (TI) paling rendah karena diduga tumpukan seresah akibat peluruhan pelepah maupun daun-daun sawit pada TI menyebabkan banyaknya jenis tumbuhan bawah yang mati. Faktor lain yang mempengaruhi yaitu penutupan tajuk pada kedua kondisi kebun ini juga lebih tertutup sehingga cahaya matahari yang masuk lebih sedikit dan mengakibatkan dapat menekan pertumbuhan dormansi jenis tumbuhan bawah. Berdasarkan hasil analisis tanah, kondisi $\mathrm{pH}$ tanah merupakan hal yeng menonjol. Pada kondisi sawit TM 5,8 sedangkan utnuk TI cukup jauh perbedaannya yaitu 4,5 sehingga lebih asam. kebun kelapa sawit yang muda (TI) ditemukan 20 jenis yang terdiri dari 8 jenis asli dan 12 jenis asing.

2. Tingkat keragaman jenis tumbuhan bawah (H') pada kebun kelapa sawit yang berada di PT. Bio Nusantara Teknologi tergolong rendah dengan besaran masing-masing pada TI dengan nilai 1,94 dan TM sebesar 0,637. Jenis 
yang mendominasi pada ketiga kondisi kebun kelapa sawit adalah Axonopus compressus dengan INP 130,238\% (TM) dan 42,237\% (TI).

\section{DAFTAR PUSTAKA}

Istomo dan Kusmana C. 1997. Penuntun Praktikum Ekologi Hutan. Laboratorium Ekologi Hutan. Fakultas Kehutanan. Institur Pertanian Bogor. Bogor.

Kasmo. 1986. Beberapa gulma penting pada tanaman pangan dan cara pengendaliannya. Direktorat Jendral Pertanian Tanaman Pangan. Jakarta.

Moenandir, J. 1993. Pengantar ilmu dan pengendalian gulma. PT Raja Grafindo Persada . Jakarta

Novitria, B.L. 2014. Pertelaan Axonopus compressus.

file:///E:/Briskha_Lejar_Novitria's $\% 20$ Blog.html (5 April 2018)

Nursyiwan. 2014. Optimalisasi lahan suboptimal melalui penanaman
Mucuna bracteata. Hal 357-361. Prosiding Seminar Nasional Lahan Suboptimal 2014. Palembang. 26-27 September 2014.

Pananjung, W.G. 2013. Keanekaragaman jenis tumbuhan bawah pada tegakan sengon buto (enterolobium cyclocarpum griseb.) dan trembesi (samanea saman merr.) di lahan pasca tambang batubara Pt Kitadin, Embalut, Kutai Kartanegara, Kalimantan Timur. Skripsi. Fakultas Kehutanan Departemen Silvikultur. Institut Pertanian Bogor, Bogor (tidak dipublikasikan).

Syahputra., E, Sarbino., dan S. Dian. 2011. Weeds assessment di perkebunan kelapa sawit lahan gambut. Jurnal Tek. Perkebunan \& PSDL vol 1 : 3742.

Wiryono. 2009. Ekologi hutan. Universitas Bengkulu Press. Bengkulu. 